\title{
Using MSN Money To Perform Financial Ratio Analysis
}

H. Christine Hsu, California State University, Chico, USA

\begin{abstract}
In today's information technology world, real time financial data is readily available via many financial websites, such as MSN Money, Google Finance, Yahoo Finance, etc. The incorporation of computer technology in finance classes has become more popular than ever in this information technology rich environment. Mediated classrooms have rapidly grown in numbers throughout the universities worldwide. Based on my experience as a finance professor, I have summarized this teaching note to demonstrate an alternative pedagogical tool in performing financial ratio analysis. The class assignment presented hereinafter is designed to help students learn how to assess the company's overall operations and current financial standing via an on-line database available in MSN Money website. It can be used in any corporate finance class. I collected student feedback on the assignment, and the vast majority of the survey participants perceived the assignment as a very good learning experience.
\end{abstract}

Keywords: financial ratio analysis, Du Pont analysis

\section{INTRODUCTION}

ef

inancial ratio analysis is an important topic and is covered in all mainstream corporate finance textbooks. It is widely used to summarize the information in a company's financial statements so as to analyze its financial condition and performance. In today's information technology world, real time financial data is readily available via many financial websites, such as MSN Money, Google Finance, Yahoo Finance, etc. As students now have easy access to on-line financial databases, professors can now modify class assignments on ratio analysis accordingly to enhance teaching effectiveness and student learning. Based on my experience as a finance professor, I have summarized this teaching note to demonstrate an alternative pedagogical tool in performing financial ratio analysis. The class assignment presented hereinafter is designed to help students learn how to assess the company's overall operations and current financial standing via an on-line database available in MSN Money website. It can be used in any corporate finance class.

\section{THE FINANCIAL RATIO ANALYSIS ASSIGNMENT}

Students work on the assignment collaboratively in groups of four to five. Each group selects an industry of interest and each student selects a company within that industry. The assignment requires that all companies in a student group belong to the same industry as defined in MSN Money website ${ }^{1}$. Each student downloads the relevant financial data from the Internet and performs ratio analysis for the selected company. Since successful financial ratio analysis is as much an art as it is a science, students must use common sense and sound judgment throughout the \footnotetext{
within the same industry as defined in MSN Money website:

- $\quad$ Go to MSN Money home page (http://moneycentral.msn.com/home.asp)

- $\quad$ Scroll down to Investing, click on Stock Research $\rightarrow$ Find Stocks $\rightarrow$ Stock Screener

- $\quad$ Select Company Basics $\rightarrow$ Industry (select your industry) $\rightarrow$ Run Search

- $\quad$ A list of the companies in the selected industry will appear.
}

${ }^{1}$ MSN Money website provides enterprise-wide business news, stock market data, and research solutions. To select companies 
analysis. The purpose of this assignment is to provide students with the opportunity to:

- $\quad$ Retrieve real time financial data via the Internet;

- $\quad$ Identify relevant financial information;

- $\quad$ Analyze the financial condition and performance of a selected company;

- $\quad$ Enhance EXCEL skills;

- $\quad$ Enhance teamwork skills; and

- $\quad$ Practice communication skills, both in writing (through word processing) and in speaking (through giving a PowerPoint presentation).

\section{Trend Analysis}

To evaluate how the company has been performing over time, at least three years' financial ratios are required. Students are to follow the path below to retrieve financial statements of the selected companies.

- $\quad$ Go to MSN Money home page (http://moneycentral.msn.com/home.asp).

- $\quad$ Enter Company Symbol or Name:

- $\quad$ On Company page, double click on Financial Results $\rightarrow$ Statements.

- $\quad$ Download the annual Income Statements and Balance Sheets. See APPENDIX 1 for a sample of Oracle's financial statements.

The downloaded financial statements are to be used to calculate relevant financial ratios listed below.

- $\quad$ Liquidity ratios (current ratio, quick ratio and interval measure) - to measure the company's ability to pay its bills.

- Asset management ratios (asset turnover, inventory turnover and receivable turnover) - to measure the company's ability in utilizing its assets.

- Debt management ratios (debt to assets ratio and interest coverage) - to measure the extent to which the company's assets are financed with debt and the company's ability to service the debt.

- Profitability ratios (net profit margin, return on assets, return on equity and return on capital) - to measure the company's ability in generating earnings.

- $\quad$ Market value measures (market value added, price to book value and price to earnings) - to measure how the investors in the market perceive the company.

For example, to compute the interval measure (= quick assets/daily operating expenditures) in the area of liquidity, students are required to obtain quick assets (= cash and short-term investments + receivables) from the balance sheets and operating expenditures from the income statements, and calculate this ratio to measure how long the company can keep up with its bills using only those current assets readily convertible to cash. To compute the interest coverage ratio (= earnings before interest and taxes/interest expenses) in the area of debt management, students are required to obtain the earnings and interest expenses from the income statements, and calculate this ratio to measure the company's ability to service the debt. To report how much market value is created for the company's shareholders, students are required to compute market value added (MVA), the difference between the market capitalization (= stock price * \# of common shares outstanding) and the equity book value (= capital invested by the company's shareholders), based upon the stock price as of the balance sheet date, \# of common shares outstanding and total shareholders' equity from the balance sheets. The financial ratios in each of the performance are analyzed across time when they are complete. The professor should require the students to report the company's financial health as of the balance sheet date and whether the company is financially better off this year than it was last year. See Table 1 for a sample trend analysis for Oracle Corp. 
Table 1: Oracle Trend Analysis

\begin{tabular}{|l|c|c|c|l|}
\hline \multicolumn{1}{|c|}{ Performance Area } & $\mathbf{2 0 0 9}$ & $\mathbf{2 0 0 8}$ & $\mathbf{2 0 0 7}$ & \multicolumn{1}{|c|}{ Trend } \\
\hline Leverage: & & & & Mixed leverage \\
\hline Debt to Assets (\%) & 47.1 & 51.3 & 51.1 & Drop in leverage since 2008 \\
\hline Interest Coverage (times) & 13.4 & 19.9 & 17.9 & Lower coverage since 2008 \\
\hline Liquidity: & & & & Improving liquidity \\
\hline Current Ratio (times) & 2.0 & 1.8 & 1.4 & Increased liquidity since 2007 \\
\hline Quick Ratio (times) & 1.9 & 1.7 & 1.2 & Increased liquidity since 2007 \\
\hline Interval Measure (days) & 622.6 & 578.6 & 482.1 & Increased liquidity since 2007 \\
\hline Profitability: & & & & Deteriorating profitability \\
\hline Net Profit Margin (\%) & 24.1 & 24.6 & 23.7 & Lower profitability since 2008 \\
\hline Return on Assets (\%) & 11.8 & 11.7 & 12.4 & Lower profitability since 2007 \\
\hline Return on Equity (\%) & 22.3 & 24.0 & 25.3 & Lower profitability since 2007 \\
\hline Efficiency: & & & & Improving efficiency \\
\hline Asset Turnover (times) & 0.49 & 0.47 & 0.52 & Increased efficiency since 2008 \\
\hline Receivables Turnover (times) & 4.7 & 3.9 & 3.9 & Increased efficiency since 2008 \\
\hline Inventory Turnover (times) & $\mathrm{Na}$ & $\mathrm{Na}$ & $\mathrm{Na}$ & No inventory for Oracle \\
\hline Market Value: & & & & Deteriorating market perception \\
\hline Market Value Added (\$million) & $72,958.0$ & $94,601.0$ & $82,054.7$ & Drop in market value added \\
\hline Price to Earnings (times) & 17.5 & 21.3 & 23.2 & Drop in P/E ratio \\
\hline Price to Book Value (times) & 3.9 & 5.1 & 5.8 & Drop in Price to Book Value \\
\hline
\end{tabular}

Table 2: Oracle Du Pont Analysis

\begin{tabular}{|l|c|c|c|l|}
\hline \multicolumn{1}{|c|}{ Item / Ratio } & $\mathbf{2 0 0 9}$ & $\mathbf{2 0 0 8}$ & $\mathbf{2 0 0 7}$ & \multicolumn{1}{c|}{ Evaluation } \\
\hline $\begin{array}{l}\text { Net Income, \$million } \\
\text { (from Income statements) }\end{array}$ & $5,593.0$ & $5,521.0$ & $4,274.0$ & Higher profits since 2007 \\
\hline $\begin{array}{l}\text { Revenue, \$million } \\
\text { (from Income statements) }\end{array}$ & $23,252.0$ & $22,430.0$ & $17,996.0$ & Higher revenue since 2007 \\
\hline $\begin{array}{l}\text { Assets, \$million } \\
\text { (from balance sheets) }\end{array}$ & $47,416.0$ & $47,268.0$ & $34,572.0$ & Increased assets since 2007 \\
\hline $\begin{array}{l}\text { Equity, \$million } \\
\text { (from balance sheets) }\end{array}$ & $25,090.0$ & $23,025.0$ & $16,919.0$ & Increased equity since 2007 \\
\hline $\begin{array}{l}\text { Net Profit Margin, \% } \\
\text { (Net Income/Revenue) }\end{array}$ & 24.1 & 24.6 & 23.7 & $\begin{array}{l}\text { Increased profitability in 2008, but } \\
\text { lower profitability in 2009 }\end{array}$ \\
\hline $\begin{array}{l}\text { Asset Turnover, times } \\
\text { (Revenue/Assets) }\end{array}$ & 0.49 & 0.47 & 0.52 & Lower efficiency since 2007 \\
\hline $\begin{array}{l}\text { Return on Assets, \% } \\
\text { (Net Profit Margin* Asset Turnover) }\end{array}$ & 11.8 & 11.7 & 12.4 & $\begin{array}{l}\text { ROA declined in 2008 due to lower } \\
\text { efficiency. }\end{array}$ \\
\hline $\begin{array}{l}\text { Equity Multiplier, times } \\
\text { (Assets/Equity) }\end{array}$ & 1.89 & 2.05 & 2.04 & Drop in leverage since 2008 \\
\hline $\begin{array}{l}\text { Return on Equity, \% } \\
\text { (Return on Assets* Equity Multiplier) }\end{array}$ & 22.3 & 24.0 & 25.3 & $\begin{array}{l}\text { ROE declined in 2009 due to lower } \\
\text { profitability and leverage. }\end{array}$ \\
\hline
\end{tabular}

\section{Du Pont Analysis}

Since it is important to understand how the profitability, efficiency and leverage are linked in the company's operations, students are required to demonstrate and evaluate its Du Pont system over time. Under Du Pont system, the company's return on assets, ROA (= net income/assets), is expressed as:

$\mathrm{ROA}=($ Net Income/Revenue $) *($ Revenue/Assets $)$

$=$ Net Profit Margin * Asset Turnover

The company's return on equity, ROE (= net income/equity), is expressed as: 


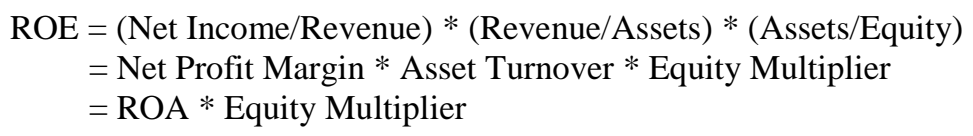

Both profitability (as measured in terms of net profit margin) and efficiency (as measured in terms of asset turnover) determine the company's ROA. This ROA along with the company's financial leverage (as measured in terms of equity multiplier) contribute to its ROE. As the company's use of leverage magnifies its ROE, students are required to examine ROE carefully. The student should note and explain the changes in the company's ROE through its profitability, efficiency, and leverage over time. The purpose is to identify the company's strong areas that can be capitalized upon and/or its weak areas that must be improved upon. See Table 2 for a sample Du Pont analysis for Oracle Corp.

\section{Industry Comparative Analysis}

To explain the variation in the company's financial ratios over time, the industry comparative analysis must be performed along with the trend analysis. The financial ratios in each of the performance areas are now analyzed across companies in the industry. The student compares the company's financial ratios with those of its key competitors, and determines whether managerial or environmental factors cause the trend of the company's financial condition and performance. To further assess the company's financial standing in its primary industry, the company and industry key ratios are retrieved via the path below.

- $\quad$ Go to MSN Money home page (http://moneycentral.msn.com/home.asp).

- $\quad$ Enter Company Symbol:

- $\quad$ On Company page, scroll down and double click on Financial Results $\rightarrow$ Key Ratios.

- Retrieve the key ratios from the following tables: Profit Margins, Financial Condition, Investment Returns, Management Efficiency, and Price Ratios. See APPENDIX 2 for Oracle and Application Software Industry Key Ratios.

- Now place the retrieved financial ratios in one of the performance areas and compare them against the industry benchmark ratios. For this part of the analysis, focus only on the financial ratios reported in MSN Money.

- Place each ratio in one of the performance areas, e.g., current ratio should be placed in the area of liquidity, return on assets should be in the area of profitability, etc. Students need to understand what each ratio measures.

- Evaluate the company's performance against the industry norm. Students need to know if it is better (or worse) to have a higher ratio and determine if the company outperforms an average firm in the industry. analysis:

The following specific industry ratios are available in MSN Money and used as benchmarks in this

- $\quad$ Liquidity measures: Current Ratio, Quick Ratio

- $\quad$ Debt management measures: Debt/Equity, Interest Coverage

- $\quad$ Profitability measures: Net Profit Margin, Return on Equity, Return on Assets, Return on Capital

- $\quad$ Asset management measures: Asset Turnover, Inventory Turnover, Receivable Turnover

- $\quad$ Market value measures: Current P/E Ratio, Price/Book Value

The student should report on how the company performs as compared to the industry norms and where the company stands in its primary industry. The weaknesses and/or strengths of the company's financial condition and performance must be identified and recommendations for improvement presented. See Table 3 for a sample industry comparative analysis for Oracle Corp. 
Table 3: Oracle vs. Application Software Industry Comparative Analysis

\begin{tabular}{|l|c|c|l|}
\hline \multicolumn{1}{|c|}{ Performance Area } & Oracle & Industry & \multicolumn{1}{c|}{ Evaluation } \\
\hline Leverage: & & & Poor leverage \\
\hline Debt/Equity (\%) & 0.54 & 0.25 & High leverage \\
\hline Interest Coverage (times) & 13.0 & 28.5 & Low coverage \\
\hline Liquidity: & & & Good liquidity \\
\hline Current Ratio (times) & 3.0 & 2.2 & High liquidity \\
\hline Quick Ratio (times) & 3.0 & 2.2 & High liquidity \\
\hline Profitability: & & & Mixed profitability \\
\hline Net Profit Margin (\%) & 25.0 & 22.4 & High profitability \\
\hline Return on Assets (\%) & 11.8 & 9.1 & High profitability \\
\hline Return on Equity (\%) & 23.0 & 27.7 & Low profitability \\
\hline Return on Capital (\%) & 14.2 & 18.2 & Low profitability \\
\hline Efficiency: & & & Mixed efficiency \\
\hline Asset Turnover (times) & 0.5 & 0.7 & Below average efficiency \\
\hline Receivable Turnover (times) & 7.3 & 6.1 & Above average efficiency \\
\hline Inventory Turnover (times) & NA & 10.7 & \\
\hline Market Value: & & & Poor/Average market perception \\
\hline Current P/E Ratio (times) & 20.5 & 20.5 & Average \\
\hline Price/Book Value (times) & 4.28 & 10.09 & Low price to book \\
\hline
\end{tabular}

\section{Case Brief and Presentation}

To reinforce the teamwork effort, each student group submits a written report summarizing the ratio analyses of the companies in the industry peer group. Students work together and produce a group report that is concise and similar in style to an executive summary with no more than three typed pages plus exhibits. Each group gives an oral presentation to brief the class on their analyses, their recommendations, and the limitations of their analyses. The professor should require charts and tables in the PowerPoint presentation. The group is also required to address the questions from the class. Both the instructor and the non-presenting students provide feedbacks regarding the presenting team's performance at the end of the presentation.

\section{Student Feedback}

To gain insight into the students' perspectives regarding the assignment, I collected feedback survey data at the end of fall semester 2008, spring semester 2009, and fall semester 2009. A total of 115 students enrolled in my upper division Financial Management classes over these three semesters participated in the survey. However, 13 were deleted from the sample due to incomplete responses. The sample consists of 102 undergraduate finance majors ( 81 seniors, 20 juniors, and 1 sophomore) over the survey semesters. Table 4 contains the survey items and results. Panel I displays the student responses (in terms of number of respondents) to each survey item by semester. Panel II provides the mean scores of the student responses based on an ordinal scale from 1 to 6 , with 1 being strongly disagree and 6 strongly agree. Overall, Panel I reveals that more than $80 \%$ of the students ( 82 or more out of 102) responded positively (with strongly/moderately/slightly agree ratings) to the survey questionnaires. Panel I also shows that $100 \%$ of the students participated in the survey (102 out of 102) either moderately or strongly agreed that the ratio analysis assignment enhanced my understanding of the role of ratios in evaluating a firm's financial performance. In fact, the vast majority of the students either moderately or strongly agreed that (1) the ratio analysis assignment enhanced my research skills in finding relevant information and materials regarding a particular firm (86 out of 102 or $84.3 \%$ ), (2) the ratio analysis assignment enhanced my ability in analyzing the basic elements of an idea, information, or experience, such as examining a particular firm in depth and considering its components (82 out of 102 or $80.4 \%$ ), (3) the ratio analysis assignment enhanced my ability in making judgments about the value of information, arguments, or methods, such as examining how others gathered and interpreted data and assessing the soundness of their conclusions (79 out of 102 or $77.5 \%$ ), (4) the ratio analysis assignment enhanced my ability in memorizing facts, formulae or methods from the courses and readings so I can repeat them in pretty much the same form (77 out of 102 or $75.5 \%$ ), (5) the ratio analysis assignment enhanced my ability in applying theories or concepts to practical problems ( 76 out of 102 or $74.5 \%$ ), (6) the ratio analysis assignment enhanced my ability in 
synthesizing and organizing ideas, information, or experiences into new, more complex interpretations and relationships (67 out of 102 or $65.7 \%$ ), (7) the ratio analysis assignment enhanced my teamwork skills (60 out of 102 or 58.8\%), and (8) the ratio analysis assignment enhanced my computer skills in producing visual displays of information, e.g., charts, graphs and spreadsheets (56 out of 102 or 54.9\%). Panel II evidences that the students from all three semesters responded positively regarding how the assignment enriched their learning experiences (with mean scores varying from 4.2 to 5.7). Virtually the survey results are consistent from semester to semester; the differences in the mean scores between any two semesters are not significant statistically (at .05 significance level).

Table 4: Student Feedback

\begin{tabular}{|c|c|c|c|c|c|c|c|c|}
\hline \multirow[b]{2}{*}{ Survey Item } & \multicolumn{7}{|c|}{$\frac{\text { Panel I }}{\text { Number of Respondents (N) }}$} & \multirow{2}{*}{ 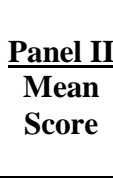 } \\
\hline & $\begin{array}{c}\text { Class } \\
(\mathbf{N})\end{array}$ & $\begin{array}{c}\text { Strongly } \\
\text { Agree }\end{array}$ & $\begin{array}{c}\text { Moderately } \\
\text { Agree }\end{array}$ & $\begin{array}{c}\text { Slightly } \\
\text { Agree }\end{array}$ & $\begin{array}{l}\text { Slightly } \\
\text { Disagree }\end{array}$ & $\begin{array}{c}\text { Moderately } \\
\text { Disagree }\end{array}$ & $\begin{array}{l}\text { Strongly } \\
\text { Disagree }\end{array}$ & \\
\hline \multirow{4}{*}{$\begin{array}{l}\text { A. The ratio analysis } \\
\text { assignment enhanced } \\
\text { my ability in } \\
\text { memorizing facts, } \\
\text { formulae or methods } \\
\text { from the courses and } \\
\text { readings so I can } \\
\text { repeat them in pretty } \\
\text { much the same form. }\end{array}$} & $\begin{array}{l}\text { F08 } \\
(38)\end{array}$ & 9 & 18 & 8 & 2 & 1 & 0 & 4.8 \\
\hline & $\begin{array}{l}\text { S09 } \\
(30)\end{array}$ & 10 & 14 & 4 & 2 & 0 & 0 & 5.1 \\
\hline & $\begin{array}{l}\text { F09 } \\
\text { (34) }\end{array}$ & 6 & 20 & 7 & 0 & 0 & 1 & 4.9 \\
\hline & $\begin{array}{l}\text { ALL } \\
(102)\end{array}$ & 25 & 52 & 19 & 4 & 1 & 1 & 4.9 \\
\hline \multirow{4}{*}{$\begin{array}{l}\text { B. The ratio analysis } \\
\text { assignment enhanced } \\
\text { my ability in } \\
\text { analyzing the basic } \\
\text { elements of an idea, } \\
\text { information, or } \\
\text { experience, such as } \\
\text { examining a } \\
\text { particular firm in } \\
\text { depth and } \\
\text { considering its } \\
\text { components. }\end{array}$} & $\begin{array}{l}\text { F08 } \\
(38)\end{array}$ & 11 & 18 & 8 & 0 & 1 & 0 & 5.0 \\
\hline & $\begin{array}{l}\text { S09 } \\
(30)\end{array}$ & 14 & 10 & 5 & 1 & 0 & 0 & 5.2 \\
\hline & $\begin{array}{l}\text { F09 } \\
(34)\end{array}$ & 11 & 18 & 5 & 0 & 0 & 0 & 5.2 \\
\hline & $\begin{array}{l}\text { ALL } \\
(102)\end{array}$ & 36 & 46 & 18 & 1 & 1 & 0 & 5.1 \\
\hline \multirow{4}{*}{$\begin{array}{l}\text { C. The ratio analysis } \\
\text { assignment enhanced } \\
\text { my ability in } \\
\text { synthesizing and } \\
\text { organizing ideas, } \\
\text { information, or } \\
\text { experiences into new, } \\
\text { more complex } \\
\text { interpretations and } \\
\text { relationships. }\end{array}$} & $\begin{array}{l}\text { F08 } \\
(38)\end{array}$ & 8 & 13 & 13 & 3 & 1 & 0 & 4.6 \\
\hline & $\begin{array}{l}\text { S09 } \\
(30)\end{array}$ & 6 & 15 & 7 & 1 & 1 & 0 & 4.8 \\
\hline & $\begin{array}{l}\text { F09 } \\
(34)\end{array}$ & 5 & 20 & 9 & 0 & 0 & 0 & 4.9 \\
\hline & $\begin{array}{l}\text { ALL } \\
(102)\end{array}$ & 19 & 48 & 29 & 4 & 2 & 0 & 4.8 \\
\hline \multirow{4}{*}{$\begin{array}{l}\text { D. The ratio analysis } \\
\text { assignment enhanced } \\
\text { my ability in making } \\
\text { judgments about the } \\
\text { value of information, } \\
\text { arguments, or } \\
\text { methods, such as } \\
\text { examining how } \\
\text { others gathered and } \\
\text { interpreted data and } \\
\text { assessing the } \\
\text { soundness of their } \\
\text { conclusions. }\end{array}$} & $\begin{array}{l}\text { F08 } \\
(38)\end{array}$ & 7 & 21 & 8 & 1 & 1 & 0 & 4.8 \\
\hline & $\begin{array}{l}\text { S09 } \\
(30)\end{array}$ & 11 & 13 & 5 & 1 & 0 & 0 & 5.1 \\
\hline & $\begin{array}{l}\text { F09 } \\
(34)\end{array}$ & 5 & 22 & 5 & 1 & 0 & 1 & 4.8 \\
\hline & $\begin{array}{l}\text { ALL } \\
(102)\end{array}$ & 23 & 56 & 18 & 3 & 1 & 1 & 4.9 \\
\hline
\end{tabular}


Table 4: continued

\begin{tabular}{|c|c|c|c|c|c|c|c|c|}
\hline \multirow[b]{2}{*}{ Survey Item } & \multicolumn{7}{|c|}{$\stackrel{\text { Panel I }}{\text { Number of Respondents (N) }}$} & \multirow{2}{*}{ 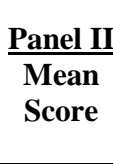 } \\
\hline & $\begin{array}{c}\text { Class } \\
(\mathbf{N})\end{array}$ & $\begin{array}{l}\text { Strongly } \\
\text { Agree }\end{array}$ & $\begin{array}{c}\text { Moderately } \\
\text { Agree }\end{array}$ & $\begin{array}{c}\text { Slightly } \\
\text { Agree }\end{array}$ & $\begin{array}{l}\text { Slightly } \\
\text { Disagree }\end{array}$ & $\begin{array}{c}\text { Moderately } \\
\text { Disagree }\end{array}$ & $\begin{array}{l}\text { Strongly } \\
\text { Disagree }\end{array}$ & \\
\hline \multirow{4}{*}{$\begin{array}{l}\text { E. The ratio analysis } \\
\text { assignment enhanced } \\
\text { my ability in } \\
\text { applying theories or } \\
\text { concepts to practical } \\
\text { problems. }\end{array}$} & $\begin{array}{l}\text { F08 } \\
(38)\end{array}$ & 10 & 18 & 7 & 2 & 1 & 0 & 4.9 \\
\hline & $\begin{array}{l}\text { S09 } \\
(30)\end{array}$ & 11 & 12 & 5 & 2 & 0 & 0 & 5.1 \\
\hline & $\begin{array}{l}\text { F09 } \\
(34)\end{array}$ & 10 & 15 & 8 & 1 & 0 & 0 & 5.0 \\
\hline & $\begin{array}{l}\text { ALL } \\
(102) \\
\end{array}$ & 31 & 45 & 20 & 5 & 1 & 0 & 5.0 \\
\hline \multirow{4}{*}{$\begin{array}{l}\text { F. The ratio analysis } \\
\text { assignment enhanced } \\
\text { my research skills in } \\
\text { finding relevant } \\
\text { information and } \\
\text { materials regarding a } \\
\text { particular firm. }\end{array}$} & $\begin{array}{l}\text { F08 } \\
(38)\end{array}$ & 21 & 10 & 4 & 2 & 1 & 0 & 5.3 \\
\hline & $\begin{array}{l}\text { S09 } \\
(30)\end{array}$ & 16 & 8 & 2 & 3 & 1 & 0 & 5.2 \\
\hline & $\begin{array}{l}\text { F09 } \\
(34)\end{array}$ & 15 & 16 & 2 & 1 & 0 & 0 & 5.3 \\
\hline & $\begin{array}{l}\text { ALL } \\
(102)\end{array}$ & 52 & 34 & 8 & 6 & 2 & 0 & 5.3 \\
\hline \multirow{4}{*}{$\begin{array}{l}\text { G. The ratio analysis } \\
\text { assignment enhanced } \\
\text { my teamwork skills. }\end{array}$} & $\begin{array}{l}\text { F08 } \\
(38)\end{array}$ & 4 & 15 & 13 & 5 & 0 & 1 & 4.4 \\
\hline & $\begin{array}{l}\text { S09 } \\
(30)\end{array}$ & 6 & 12 & 9 & 1 & 2 & 0 & 4.6 \\
\hline & $\begin{array}{l}\text { F09 } \\
(34)\end{array}$ & 6 & 17 & 8 & 2 & 1 & 0 & 4.7 \\
\hline & $\begin{array}{l}\text { ALL } \\
(102)\end{array}$ & 16 & 44 & 30 & 8 & 3 & 1 & 4.6 \\
\hline \multirow{4}{*}{$\begin{array}{l}\text { H. The ratio analysis } \\
\text { assignment enhanced } \\
\text { my computer skills in } \\
\text { producing visual } \\
\text { displays of } \\
\text { information, e.g., } \\
\text { charts, graphs and } \\
\text { spreadsheets. }\end{array}$} & $\begin{array}{l}\text { F08 } \\
(38) \\
\end{array}$ & 11 & 7 & 9 & 8 & 2 & 1 & 4.4 \\
\hline & $\begin{array}{l}\text { S09 } \\
(30)\end{array}$ & 8 & 8 & 8 & 3 & 3 & 0 & 4.5 \\
\hline & $\begin{array}{l}\text { F09 } \\
(34)\end{array}$ & 8 & 14 & 9 & 2 & 0 & 1 & 4.7 \\
\hline & $\begin{array}{l}\text { ALL } \\
(102) \\
\end{array}$ & 27 & 29 & 26 & 13 & 5 & 2 & 4.5 \\
\hline \multirow{4}{*}{$\begin{array}{l}\text { I. The ratio analysis } \\
\text { assignment enhanced } \\
\text { my communication } \\
\text { skills. }\end{array}$} & $\begin{array}{l}\text { F08 } \\
(38) \\
\end{array}$ & 3 & 12 & 14 & 7 & 1 & 1 & 4.2 \\
\hline & $\begin{array}{l}\text { S09 } \\
(30)\end{array}$ & 4 & 12 & 10 & 3 & 1 & 0 & 4.5 \\
\hline & $\begin{array}{l}\text { F09 } \\
(34)\end{array}$ & 4 & 12 & 15 & 1 & 1 & 1 & 4.4 \\
\hline & $\begin{array}{l}\text { ALL } \\
(102)\end{array}$ & 11 & 36 & 39 & 11 & 3 & 2 & 4.3 \\
\hline \multirow{4}{*}{$\begin{array}{l}\text { J. The ratio analysis } \\
\text { assignment enhanced } \\
\text { my understanding of } \\
\text { the role of ratios in } \\
\text { evaluating a firm's } \\
\text { financial } \\
\text { performance. }\end{array}$} & $\begin{array}{l}\text { F08 } \\
(38)\end{array}$ & 26 & 12 & 0 & 0 & 0 & 0 & 5.7 \\
\hline & $\begin{array}{l}\text { S09 } \\
(30)\end{array}$ & 17 & 13 & 0 & 0 & 0 & 0 & 5.6 \\
\hline & $\begin{array}{l}\text { F09 } \\
(34)\end{array}$ & 13 & 21 & 0 & 0 & 0 & 0 & 5.4 \\
\hline & $\begin{array}{l}\text { ALL } \\
(102)\end{array}$ & 56 & 46 & 0 & 0 & 0 & 0 & 5.6 \\
\hline
\end{tabular}

Scale: 1 = Strongly Disagree; 2 = Moderately Disagree; 3 = Slightly Disagree; 4 = Slightly Agree; $5=$ Moderately Agree; $6=$ Strongly Agree 
I encouraged student written comments, which were collected from the survey questionnaires as well. Some students expressed their dissatisfaction about working together as a group: "Because of groups people can try to get out of doing certain work or just do the bare minimum." "Though this was a group project, my group did not do much work together." "Team assignments always get left to half the group members doing the work." This could explain why the survey items on communication skills, computer skills, and teamwork skills (in producing group reports and oral presentations) are rated at the bottom, with mean scores of 4.3, 4.5, and 4.6, respectively. Nonetheless, the students' written comments on the assignment were generally favorable: 'I truly appreciate the ratio analysis assignment because I have not experienced a real world analysis of companies and industries in any other classes. I strongly recommend continuing and expanding the assignment." "I thought it was a good assignment to apply what we have learned in classes to a real life situation. Often times in finance classes, we don't see how what we are learning is used in the real world. This project helped us understand how ratio analysis is applied." "I think that we should have done more assignments like the ratio analysis project because I learned a lot from it." "It is a good learning experience." "The ratio analysis was interesting. Calculations and teamwork helped bring in real world interactions linking school to work environment."

Overall, the students who participated in the survey questionnaires agreed that the assignment enhanced their skills and ability in performing financial ratio analysis and generated a variety of good educational experiences.

\section{CONCLUSION}

The incorporation of computer technology in finance classes has become more popular than ever in this information technology rich environment. Mediated classrooms have grown rapidly in numbers throughout the universities worldwide. This teaching note demonstrates how finance professors and students can take advantage of the changing environment. Students can retrieve the company real time financial data from a finance website such as MSN Money and analyze its financial condition and performance across time and against its peer group. The assignment presented in this article is designed to help students learn how to assess the company's overall operations and current financial standing via the company's financial statements, teamwork and state of the art computer technology. It can be used in any corporate finance class. To gain insight into the students' perspectives regarding the assignment, I collected feedback data over three semesters. The students who participated in the survey questionnaires responded favorably to the assignment and perceived it as a very good learning experience.

\section{AUTHOR INFORMATION}

H. Christine Hsu is a professor of finance at California State University, Chico. She has taught both graduate and undergraduate finance courses at Chico State since 1985. Her research interests include capital budgeting, security analysis \& portfolio management, and enterprise resource planning in financial management. Her research manuscripts are published in various refereed journals, including Journal of Financial Research, Financial Accountability and Management, Journal of Financial and Strategic Decisions, International Business \& Economics Research Journal, Review of Business Information Systems, Business Quest, among others.

\section{REFERENCES}

1. Block, S.B. and G.A. Hirt. Foundations of Financial Management (2008), $12^{\text {th }}$ Edition, McGraw-Hill/Irwin.

2. Brealey, R.A. and S.C. Myers. Principles of Corporate Finance (2008), $9^{\text {th }}$ Edition, McGraw-Hill/Irwin.

3. Brealey, R.A., S.C. Myers and A.J. Marcus. Fundamentals of Corporate Finance (2009), $6^{\text {nd }}$ Edition, McGrawHill/Irwin.

4. Brigham, E.F., L.C. Gapenski and M.C. Ehrhardt. Financial Management: Theory and Practice (2008), $12^{\text {th }}$ Edition, Thomson South-Western.

5. Van Horne, J.C. and J.M. Wachowicz. Fundamentals of Financial Management (2009), $13^{\text {th }}$ Edition, PrenticeHall, Inc.

6. Ross, S.A., R.W. Westerfield and B.D. Jordan. Fundamentals of Corporate Finance (2008), $8^{\text {th }}$ Edition, McGraw-Hill/Irwin.

7. Ross, S.A., R.W. Westerfield and J. Jaffe. Corporate Finance (2008), $8^{\text {th }}$ Edition, McGraw-Hill/Irwin.

8. Keown, A., J.D. Martin, J.W. Petty and D.F. Scott. Foundations of Finance: The Logic and Practice of Financial Management (2008), $6^{\text {th }}$ Edition, Prentice-Hall, Inc.

9. Gitman, L. J. Principles of Managerial Finance (2007), $12^{\text {th }}$ Edition, Addison Wesley. 


\section{APPENDIX 1: The Financial Statements for Oracle}

Financial data in U.S. Dollars

Values in Millions (Except for per share items)

\section{Income Statements}

\begin{tabular}{lrrr} 
& $\mathbf{2 0 0 9}$ & $\mathbf{2 0 0 8}$ & $\mathbf{2 0 0 7}$ \\
\hline Period End Date & $5 / 31 / 2009$ & $5 / 31 / 2008$ & $5 / 31 / 2007$ \\
\hline Total Revenue & $23,252.00$ & $22,430.00$ & $17,996.00$ \\
Cost of Revenue, Total & $4,794.00$ & $4,981.00$ & $4,191.00$ \\
Gross Profit & $18,458.00$ & $17,449.00$ & $13,805.00$ \\
Selling/General/Administrative Expenses, Total & $5,530.00$ & $5,644.00$ & $4,599.00$ \\
Research \& Development & $2,767.00$ & $2,741.00$ & $2,195.00$ \\
Depreciation/Amortization & $1,713.00$ & $1,212.00$ & 878.00 \\
Unusual Expense (Income) & 127.00 & 8.00 & 159.00 \\
Operating Income & $8,321.00$ & $7,844.00$ & $5,974.00$ \\
Other, Net & 3.00 & 67.00 & 86.00 \\
Income Before Tax & $7,834.00$ & $7,834.00$ & $5,986.00$ \\
Income Tax - Total & $2,241.00$ & $2,313.00$ & $1,712.00$ \\
Income After Tax & $5,593.00$ & $5,521.00$ & $4,274.00$ \\
Net Income & $5,593.00$ & $5,521.00$ & $4,274.00$ \\
& & & \\
Dividends per Share - Common Stock & 0.05 & 0 & 0 \\
Gross Dividends - Common Stock & 250.00 & 0 & 0 \\
Interest Expense, Supplemental & 630.00 & 394.00 & 343.00 \\
Normalized EBITDA & $10,411.00$ & $9,320.00$ & $7,260.00$ \\
Normalized EBIT & $8,448.00$ & $7,852.00$ & $6,133.00$ \\
\hline
\end{tabular}

\section{Balance Sheets}

\begin{tabular}{lrrr} 
& $\mathbf{2 0 0 9}$ & $\mathbf{2 0 0 8}$ & $\mathbf{2 0 0 7}$ \\
\hline Period End Date & $5 / 31 / 2009$ & $5 / 31 / 2008$ & $5 / 31 / 2007$ \\
\hline Assets & & & \\
Cash and Short Term Investments & $12,624.00$ & $11,043.00$ & $7,020.00$ \\
Cash \& Equivalents & $8,995.00$ & $8,262.00$ & $6,218.00$ \\
Short Term Investments & $3,629.00$ & $2,781.00$ & 802.00 \\
Total Receivables, Net & $4,985.00$ & $5,799.00$ & $4,589.00$ \\
Total Inventory & 0 & 0 & 0 \\
Prepaid Expenses & 311.00 & 408.00 & 306.00 \\
Other Current Assets, Total & 6661.00 & 853.00 & 968.00 \\
Total Current Assets & $18,581.00$ & $18,103.00$ & $12,883.00$ \\
& & & \\
Property/Plant/Equipment, Total - Net & $1,922.00$ & $1,688.00$ & $1,603.00$ \\
Goodwill, Net & $18,842.00$ & $17,991.00$ & $13,479.00$ \\
Intangibles, Net & $7,269.00$ & $8,395.00$ & $5,964.00$ \\
Other Long Term Assets, Total & 802.00 & $1,091.00$ & 643.00 \\
Total Assets & $47,416.00$ & $47,268.00$ & $34,572.00$
\end{tabular}


Liabilities and Shareholders' Equity

\begin{tabular}{lrrr}
\hline Accounts Payable & 271.00 & 383.00 & 315.00 \\
Accrued Expenses & $1,612.00$ & $2,078.00$ & $1,550.00$ \\
Current Port. of LT Debt/Capital Leases & $1,001.00$ & $1,001.00$ & $1,358.00$ \\
Other Current Liabilities, Total & $6,265.00$ & $6,567.00$ & $6,164.00$ \\
Total Current Liabilities & $9,149.00$ & $10,029.00$ & $9,387.00$ \\
& & & \\
Total Long Term Debt & $9,237.00$ & $10,235.00$ & $6,235.00$ \\
Long Term Debt & $9,237.00$ & $10,235.00$ & $6,235.00$ \\
Deferred Income Tax & 480.00 & $1,218.00$ & $1,121.00$ \\
Minority Interest & 0 & 0 & 316.00 \\
Other Liabilities, Total & $3,460.00$ & $2,761.00$ & 594.00 \\
Total Liabilities & $22,326.00$ & $24,243.00$ & $17,653.00$ \\
& & & \\
Common Stock & $12,980.00$ & $12,446.00$ & $10,293.00$ \\
Retained Earnings (Accumulated Deficit) & $11,894.00$ & $9,961.00$ & $6,223.00$ \\
Other Equity, Total & 216.00 & 618.00 & 403.00 \\
Total Equity & $25,090.00$ & $23,025.00$ & $16,919.00$ \\
Total Liabilities \& Shareholders' Equity & $47,416.00$ & $47,268.00$ & $34,572.00$ \\
& & & \\
Total Common Shares Outstanding & $5,005.00$ & $5,150.00$ & $5,107.00$ \\
\hline Da prids
\end{tabular}

Data providers

Copyright (C) 2009 Thomson Reuters.

Quotes supplied by Interactive Data. 


\section{APPENDIX 2: Oracle and Application Software Industry Key Ratios}

\begin{tabular}{|c|c|c|}
\hline Profit Margins \% & Company & Industry \\
\hline Gross Margin & 81.1 & 77.0 \\
\hline Pre-Tax Margin & 35.1 & 19.0 \\
\hline Net Profit Margin & 25.0 & 22.4 \\
\hline 5Yr Gross Margin (5-Year Avg.) & 77.9 & 77.3 \\
\hline 5Yr PreTax Margin (5-Year Avg.) & 34.0 & 26.6 \\
\hline 5Yr Net Profit Margin (5-Year Avg.) & 24.1 & 17.5 \\
\hline Financial Condition & Company & Industry \\
\hline Debt/Equity Ratio & 0.54 & 0.25 \\
\hline Current Ratio & 3.0 & 2.2 \\
\hline Quick Ratio & 3.0 & 2.2 \\
\hline Interest Coverage & 13.0 & 28.5 \\
\hline Leverage Ratio & 2.0 & 1.9 \\
\hline Book Value/Share & 5.5 & 5.42 \\
\hline Investment Returns \% & Company & Industry \\
\hline Return On Equity & 23.0 & 27.7 \\
\hline Return On Assets & 11.8 & 9.1 \\
\hline Return On Capital & 14.2 & 18.2 \\
\hline Return On Equity (5-Year Avg.) & 26.3 & 26.2 \\
\hline Return On Assets (5-Year Avg.) & 13.4 & 14.8 \\
\hline Return On Capital (5-Year Avg.) & 18.0 & 21.5 \\
\hline Management Efficiency & Company & Industry \\
\hline Income/Employee & 67,465 & 107,975 \\
\hline Revenue/Employee & 270,070 & 441,453 \\
\hline Receivable Turnover & 7.3 & 6.1 \\
\hline Inventory Turnover & NA & 10.7 \\
\hline Asset Turnover & 0.5 & 0.7 \\
\hline Price Ratios & Company & Industry \\
\hline Current P/E Ratio & 20.5 & 20.5 \\
\hline P/E Ratio 5-Year High & 30.6 & 4.9 \\
\hline P/E Ratio 5-Year Low & 13.7 & 2.3 \\
\hline Price/Sales Ratio & 5.07 & 5.95 \\
\hline Price/Book Value & 4.28 & 10.09 \\
\hline Price/Cash Flow Ratio & 15.1 & 15.8 \\
\hline
\end{tabular}

Data providers

Copyright @ 2009 Thomson Reuters.

Quotes supplied by Interactive Data. 
NOTES 